\title{
Ynezidinium, a new genus within the Gonyaulacaceae (fossil Dinophyceae)
}

\author{
JOYCE LUCAS-CLARK ${ }^{1} \&$ JAVIER HELENES ${ }^{2}$ \\ ${ }^{1}$ Clark Geological Services, 1023 Old Canyon Rd, Fremont, California, CA 94536, USA. \\ ${ }^{2}$ CICESE, Departamento de Geologia, Ensenada, Baja California, Mexico.
}

\begin{abstract}
Ynezidinium malloyi gen. nov., sp. nov. shows paratabulation details that indicate it belongs to the Family Gonyaulacaceae, subfamily Leptodiniodeae, but which, in combination, distinguish it from previously described genera. The paratabulation details include: (1) pentagonal sixth precingular (1i) in contact with both fourth and first apicals (A and 1u); (2) elongate and subparallel fourth and first apicals; (3) straight to slightly sigmoidal sulcal region; (4) lack of small intercalary (K) paraplates; and (5) $\mathrm{Q} / \mathrm{B}$ preapical arrangement. Other species herein assigned to Ynezidinium include: Ynezidinium brevisulcatum (Michoux, 1985) comb. nov., Y. latolineatum (Yun, 1981) comb. nov., Y. pentahedrias (Damassa, 1979) comb. nov. and Y. waipawaense (Wilson, 1988) comb. nov. J. Micropalaeontology, 19:(2) 113-121, December 2000.
\end{abstract}

\section{INTRODUCTION}

This paper describes a new genus and species of dinoflagellate cyst, Ynezidinium malloyi gen. nov., sp. nov., recorded during palynological analysis of Palaeocene strata of the western Santa Ynez Mountains of Santa Barbara County, California, USA (Fig. 1). The species was found in two samples of Palaeocene (Bulitian) age from the Anita Formation, near the type section of the Bulitian Stage. Four species already described in the literature are newly combined with the new genus based on their morphological similarities to $Y$. malloyi, and their morphological distinctions from previously described genera. In this paper, taxonomy of published dinoflagellate species follows Lentin \& Williams (1993).

Species included in this new genus present an L-type (or $1 \mathbf{u} / 1$ i) ventral paratabulation arrangement and neutral torsion of the hypocyst. These characteristics indicate that Ynezidinium should be included in the Leptodinioidae subfamily of Fensome et al. (1993). This particular paratabulation pattern also occurs in the species: Ynezidinium brevisulcatum (Michoux, 1985) comb. nov., $Y$. latolineatum (Yun, 1981) comb. nov., Y. pentahedrias (Damassa 1979) comb. nov. and Y. waipawaense (Wilson 1988) comb. nov.

\section{MATERIAL AND METHODS}

Ynezidinium malloyi was found in the Palaeocene beds of the Anita Formation in Bulito Canyon, of the western Santa Ynez Mountains of Santa Barbara County, California (Figs 1, 2; Clark, 1981a,b). The Anita Formation (Kelley, 1943) consists of about $350 \mathrm{~m}$ of dark grey marine shale and has been assigned Cretaceous, Palaeocene and early Eocene ages based on foraminiferal biostratigraphy (Mallory, 1959; Sullivan, 1964; Gibson, 1976). Mallory (1959) used benthic Foraminifera to typify the Ynezian and Bulitian stages of the Palaeocene in the Anita Formation of Arroyo El Bulito.

A considerable controversy persists about the reconciliation of various micropalaeontological studies of the Bulito Canyon stratigraphic section (Clark, 1981a; Fredericksen, 1989). Although the samples which contain $Y$. malloyi (REM86 and REM87) are barren of calcareous fossils, other samples above and below were analysed for Foraminifera by Al Almgren (formerly of Union Oil Company of California). According to Almgren (pers. comm., 1979), the two samples containing $Y$. malloyi are Bulitian in age. The column published by Gibson

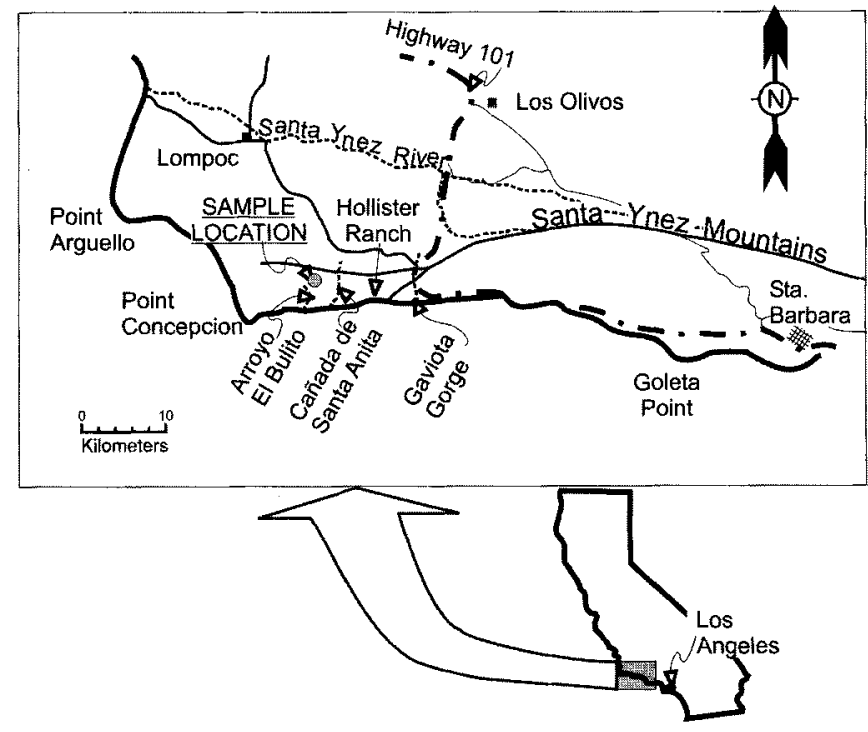

Fig. 1. Location map showing position of the Santa Ynez Mountain Range in California, USA, and the sample location on the Hollister Ranch near Santa Barbara, on the east side of Arroyo El Bulito.

(1976) agrees well with the measured section used by LucasClark (Clark, 1981a), and the samples in question seem to lie between Gibson's samples 44 and 46 , both of which contain predominantly arenaceous foraminifers which may be either Ynezian or Bulitian in age. Based on planktonic foraminifers from other samples, Gibson places samples 44 and 46 in the late Palaeocene, P-4 interval of Berggren (1971), while based on nannoplankton, Bukry (in Gibson, 1976) places them in the Discoaster mohleri zone, equivalent to NP7 of Martini (1971).

The samples were collected by Raymond Malloy on behalf of Union Oil Company of California (now UNOCAL), and processed in Union Oil Company's laboratory. Most preservation of palynomorphs was fair. Some redeposited Cretaceous palynomorphs (e.g. Dinogymnium spp.) were noted. Other species of dinoflagellates noted include: Cerodinium striatum (Drugg, 1967) Lentin \& Williams, 1987; Cerodinium speciosum (Alberti, 1959) Lentin \& Williams, 1987; Spiniferella cornutus (Gerlach, 1961) Stover \& Hardenbol, 1993; Spiniferites pseudofurcatus? (Klumpp, 1953) Sarjeant, 1970; Spiniferites speciosus 


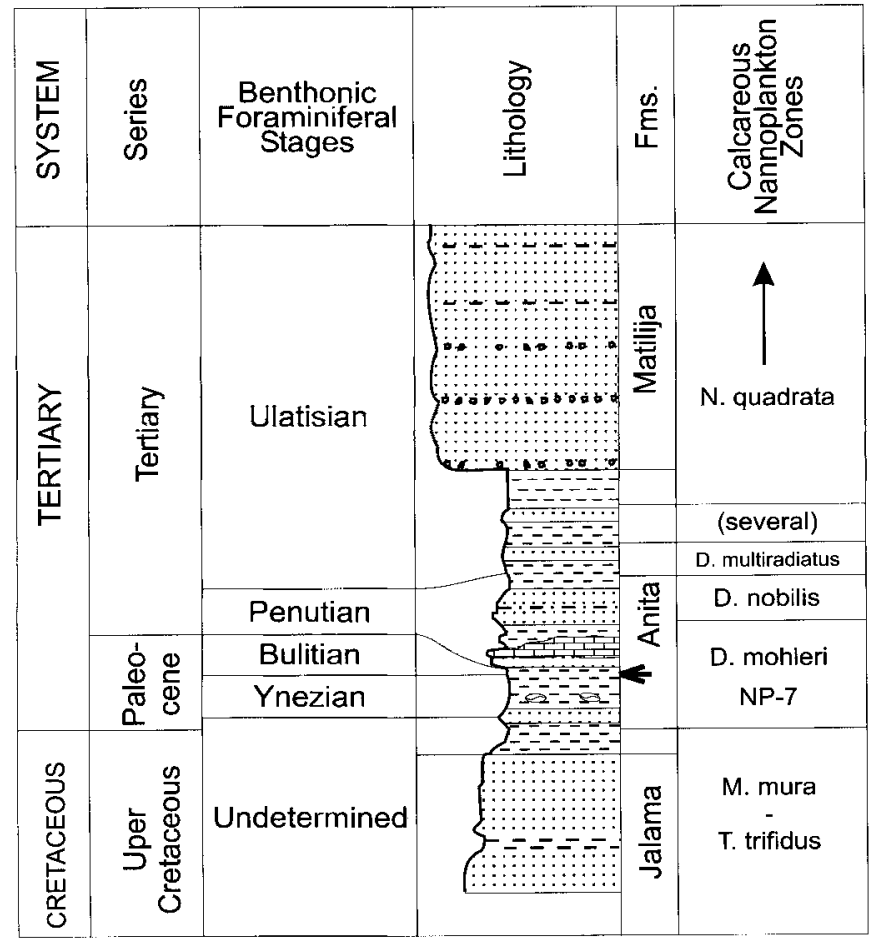

= Placement of Samples RM86 and RM87.

Fig. 2. Generalized stratigraphic column from Arroyo El Bulito (after Kleinpell \& Weaver, 1963) showing planktonic foraminiferal stages according to Mallory (1959) and calcareous nannoplankton zones according to Bukry (in Gibson, 1976)

(Deflandre, 1937) Sarjeant, 1970. Miospores include: Caryapollenites imparalis Nicols \& Ott, 1978; Ilex sp.; Nyssa puercoensis Anderson, 1960, Podocarpus spp.; Stenozonotriletes stelatus Khlonova, 1960 and Tsuga sp. (see Fredericksen, 1989).

Two slides of each sample were studied using light microscopy. The sample REM86 was reprocessed and specimens of $Y$. malloyi picked for individual study using light microscopy and SEM. Type material of $Y$. malloyi (Plate 1) presently resides with J. Lucas-Clark at Clark Geological Services in Fremont CA, but will be lodged in the Carnegie Museum of Natural History under the reference number CM 19082.

New combinations of other species are based on study of published photographs of type material and, in some cases study of specimens other than type material. The following list includes the species studied directly under the microscope and shown in Plate 2. For additional information on some of the palynomorph assemblages found with these taxa, reference is made to specific publications. The morphology of other species discussed in this paper was studied from the literature.

- Y. pentahedrias comb. nov. Palaeocene, Bateque Formation in Baja California, Mexico (Helenes, 1984a).

- Leptodinium mirabile Klement, 1960. Late Jurassic (Oxfordian), Naknek Formation in Amber Bay, Alaska . (Specimens in Stanford Palynological Collection, slides at CISESE.)
- Ochetodinium romanum Damassa, 1979. Early Eocene, limestone concretion in shaly Franciscan Melange in California (Damassa, 1979).

- Impagidinium californiense Damassa, 1979. Early Eocene, Tarras Ton (London Clay equivalent) Fehmarn Island, Baltic Sea (Morgenroth, 1966).

When describing and discussing paratabulation in this paper, the notation used is that described by Taylor (1980) and Evitt (1985). The Taylor-Evitt notation highlights plate homologies and, in our opinion is advantageous when comparing gonyaulacoid patterns. For a more detailed discussion on the advantages of using the Taylor-Evitt notation system, the reader is referred to Helenes (1984b, 1986). The conventional Kofoidian notation equivalents are as follows: Preapical series: $\mathrm{p}=1 \mathrm{pr} ; \mathrm{q}=2 \mathrm{pr}$. Apical series: $1 \mathrm{u}=1^{\prime} ; \mathrm{B}=2^{\prime} ; \mathrm{C}=3^{\prime} ; \mathrm{A}=4^{\prime}$. Precingular series: $2=1^{\prime \prime} ; 3=2^{\prime \prime} ; 4=3^{\prime \prime} ; 5=4^{\prime \prime} ; 6=5^{\prime \prime}$; $1 \mathrm{i}=6^{\prime \prime}$. Cingular series: $\mathrm{au}=1 \mathrm{c} ; \mathrm{b}=2 \mathrm{c} ; \mathrm{c}=3 \mathrm{c} ; \mathrm{d}=4 \mathrm{c}$; $\mathrm{e}=5 \mathrm{c} ; \mathrm{fi}=6 \mathrm{c}$. Sulcals: $\mathrm{ai}=\mathrm{as} ; \mathrm{fu}=\mathrm{rs} ; \mathrm{Z}=\mathrm{ps}$. Postcingulars: $\mathrm{Iu}=1^{\prime \prime \prime} ; \mathrm{II}=2^{\prime \prime \prime} ; \mathrm{III}=3^{\prime \prime \prime} ; \mathrm{IV}=4^{\prime \prime \prime} ; \mathrm{V}=5^{\prime \prime \prime} ; \mathrm{VI}=6^{\prime \prime \prime}$. Posterior intercalary: $\mathrm{X}=1 \mathrm{p}$. Antapical: $\mathrm{Y}=\mathbf{1}^{\prime \prime \prime \prime}$.

\section{SYSTEMATIC PALAEONTOLOGY}

Division Dinoflagellata (Butschili, 1885) Fensome et al., 1993

Subdivision Dinokaryota Fensome et al., 1993 Class Dinophyceae Pascher, 1914

Subclass Peridiniphycidae Fensome et al., 1993 Order Gonyaulacales Taylor, 1980

Suborder Gonyaulacineae Fensome, et al., 1993

Family Gonyaulacaceae Lindemann, 1928

Subfamily Leptodinioideae Fensome, et al. 1993

Genus Ynezidinium gen. nov.

Derivation of name. After the Santa Ynez Mountain Range where the type species was discovered.

Type species. Ynezidinium malloyi sp. nov.

Diagnosis. Medium size, acavate cysts with parasutural crests or ridges; form spherical to ellipsoidal; circular to ovoidal (dorsoventrally compressed) in equatorial section; with or without an apical horn. Intratabular areas smooth or with sparse ornamentation of low relief. Paratabulation gonyaulacacean, $1 \mathrm{i} / 1 \mathrm{u}$, Q/B. Archeopyle precingular, type $\mathbf{P}(4)$; operculum typically reduced, rounded, free.

Paratabulation. Indicated by parasutural septa or ridges, usually clear except in sulcal and preapical regions, where parasutural ridges may be reduced or absent. The following paraplates can be observed in most specimens: two preapicals $(\mathrm{Q}, \mathrm{P})$, four apicals (A, $1 \mathrm{u}, \mathrm{B}, \mathrm{C})$, six precingulars (1i, 2-6), six cingulars (au, b-e, fi), two sulcals (ai and $Z$ ), one posterior intercalary (X), six postcingulars (Iu, II-VI), and one antapical (Y).

Apical organization. preapicals sometimes indistinct but, when discernable, Q contacts all 4 apical paraplates; $\mathrm{P}$ contacts $\mathrm{Q}, \mathrm{B}$ and $\mathrm{lu}(\mathrm{Q} / \mathrm{B}$ arrangement). Porichnion may be discernable. Dorsal apicals (B and $\mathrm{C}$ ) wide and quadrangular; ventral apicals (A and $1 \mathrm{u}$ ) elongate, subparallel, and more or less centered on the ventral side of the cyst. Paraplate A slightly smaller than lu and separated from this paraplate by a complete or nearly complete septum. 
Ventral organization. paraplates $A$ and $1 \mathrm{u}$ contact $1 \mathrm{i}(1 \mathrm{u} / \mathrm{i}$ arrangement), which is pentagonal and may be smaller than other precingulars. Ends of the cingulum offset, not overlapping.

Posterior sulcal organization pentagonal X, nearly square Z, elongate, rectangular $\mathrm{Iu}$. Sulcal region elongate and at least slightly sigmoidal; some suppression of parasutures confined to the sulcal and preapical regions. Dorsal organization archeopyle usually reduced. Neutral torsion of the hypocyst indicated. Without incidentals or small $(\mathbf{K})$ intercalaries.

Hypocystal organization sexiform, $\mathrm{Y}$ slightly asymmetrical with $\mathrm{X} / \mathrm{Y}$ and $\mathrm{III} / \mathrm{Y}$ shorter than $\mathrm{VI} / \mathrm{Y}$ and $\mathrm{V} / \mathrm{Y}$ respectively. $\mathrm{Y}$ positioned antapically or displaced onto the ventrum.

Remarks. The paratabulation features which distinguish Ynezidinium from other genera include a sixth precingular paraplate (1i or $6^{\prime \prime}$ ) that is pentagonal and makes a definite contact with both ventral apical paraplates (A and $1 \mathrm{u} ; \mathbf{1}^{\prime}$ and $4^{\prime}$ ), and a sulcal region that is straight to slightly sigmoidal, thus presenting an Ltype ventral arrangement $(1 \mathrm{u} / 1 \mathrm{i}$ in Helenes, 1986). Also, the ventral apical paraplates are elongate and subparallel, ususally with A smaller than $1 \mathrm{u}$, and there are no indications of the presence of small intercalary or incidental $(K)$ paraplates in the dorsal-apical area. Also, the preapical arrangement, when discernable, appears to be one in which $Q$ contacts all four apical paraplates (Q/B in Helenes, 1986).

Comparison. Ynezidinium differs from Impagidinium (Pl. 2, figs 9, 12; Fig. 3) and Corrudinium in having a pentagonal sixth precingular (1i) that contacts both $\mathrm{A}$ and $1 \mathrm{u}$, rather than a triangular sixth precingular that ordinarily contacts only the first apical (A). Also, when discernable, the preapical arrangement of Impagidinium appears to be a $\mathrm{P} / \mathrm{C}$ arrangement in which $\mathrm{Q}$ does not contact $\mathrm{B}$, in contrast to Ynezidinitm in which $\mathrm{Q}$ contacts all four apical paraplates (Q/B arrangement). Many species of Impagidinium show suppression of the parasuture between the first and fourth apicals, and some additional suppression of parasutures, both in the cingular and sulcal region. Suppression of parasutures has not been observed in the species assigned to Ynezidinium except in the preapical and posterior sulcal region.

The distinction between Ynezidinium and Pterodinium is inevitably unclear because the ventral paratabulation of the holotype of Pterodinium aliferum is unknown. However, Below's (1981) illustrations of several species that he assigned to Pterodinium, display ventral paratabulation similar to that of Impagidinium (A/ai), in contrast to $1 \mathrm{u} / \mathrm{li}$ of Ynezidinium.

Ynezidinium differs from Leptodinium (Pl. 2, figs 3, 6; Fig. 3) in having narrow, subparallel first (1u) and fourth (A) apicals, more or less centered on the ventral side of the cyst, rather than wide first and fourth apicals, with the fourth apical positioned more on the right side of the ventral surface and the first apical centered (see Stover \& Evitt, 1978, p. 274). The sulcal region in Ynezidinium may be slightly more sigmoidal than is typical of Leptodinium. Many species of Leptodinium display small intercalary $(K)$ paraplates, whereas there are no signs of $K$ paraplates observed in the species assigned to Ynezidinium. Also, the preapical region of Leptodinium is typically a $\mathrm{P} / \mathrm{C}$ arrangement (Helenes, 1986, text-fig. 6c, and pl. 6, figs 1, 2; Fensome et al., 1993, text-figs 84 and 85 ).

The genus Ochetodinium Damassa, 1979 (pl. 2, figs 10, 11), also presents a ventral $1 \mathrm{u} / \mathrm{li}$ arrangement and lacks the small intercalary $(\mathrm{K})$ paraplates in the apical-dorsal area. However, it

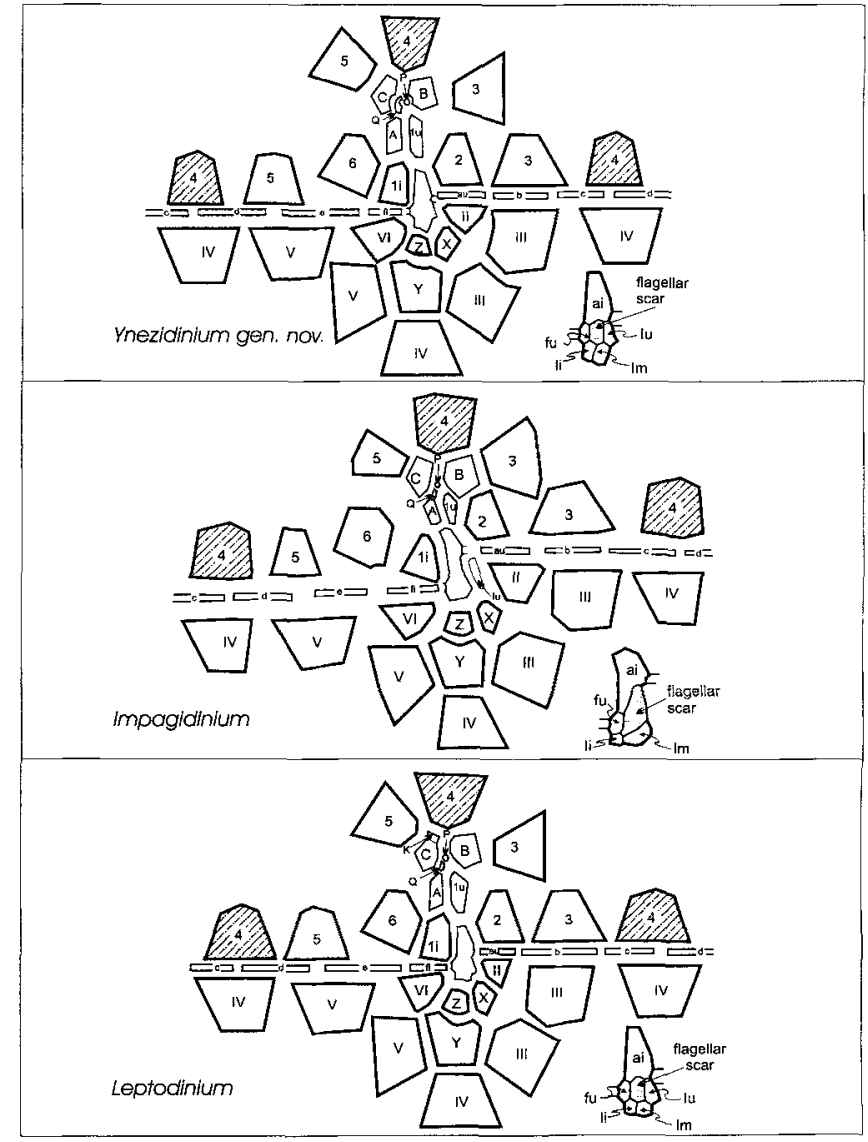

Fig. 3. Exploded diagram of genera: Ynezidinium, Leptodinium and Impagidinium.

differs from Ynezidinium in having a fairly continuous spinose to granular or vermiculate ornamentation of about the same height as the highly perforate parasutural septa and in showing dextral torsion of the hypocyst (Helenes, 1986, pl. 3, fig. 14). Also, the precingular archeopyle usually involves portions of adjacent paraplates, in contrast to the reduced archeopyle of Ynezidinium. The preapical features of Ochetodinium are not known.

Ynezidinium differs from Spiniferites and Spiniferella (pl. 2, figs 1, 2) in lacking furcate gonal spines. Additionally, Spiniferites presents an A/ai ventral arrangement (Stover \& Hardenbol, 1993).

\section{Accepted species.}

Ynezidinium malloyi sp. nov. (type species)

Ynezidinium brevisulcatum (Michoux, 1985) comb. nov.

Ynezidinium latolineatum (Yun, 1981) comb. nov.

Ynezidinium pentahedrias (Damassa, 1979) comb. nov.

Ynezidinium waipawaense (Wilson, 1988) comb. nov.

Ynezidinium malloyi sp. nov.

(Pl. 1, figs 1-10; Fig. 4)

Derivation of name. In honour of Raymond E. Malloy, palynologist. 

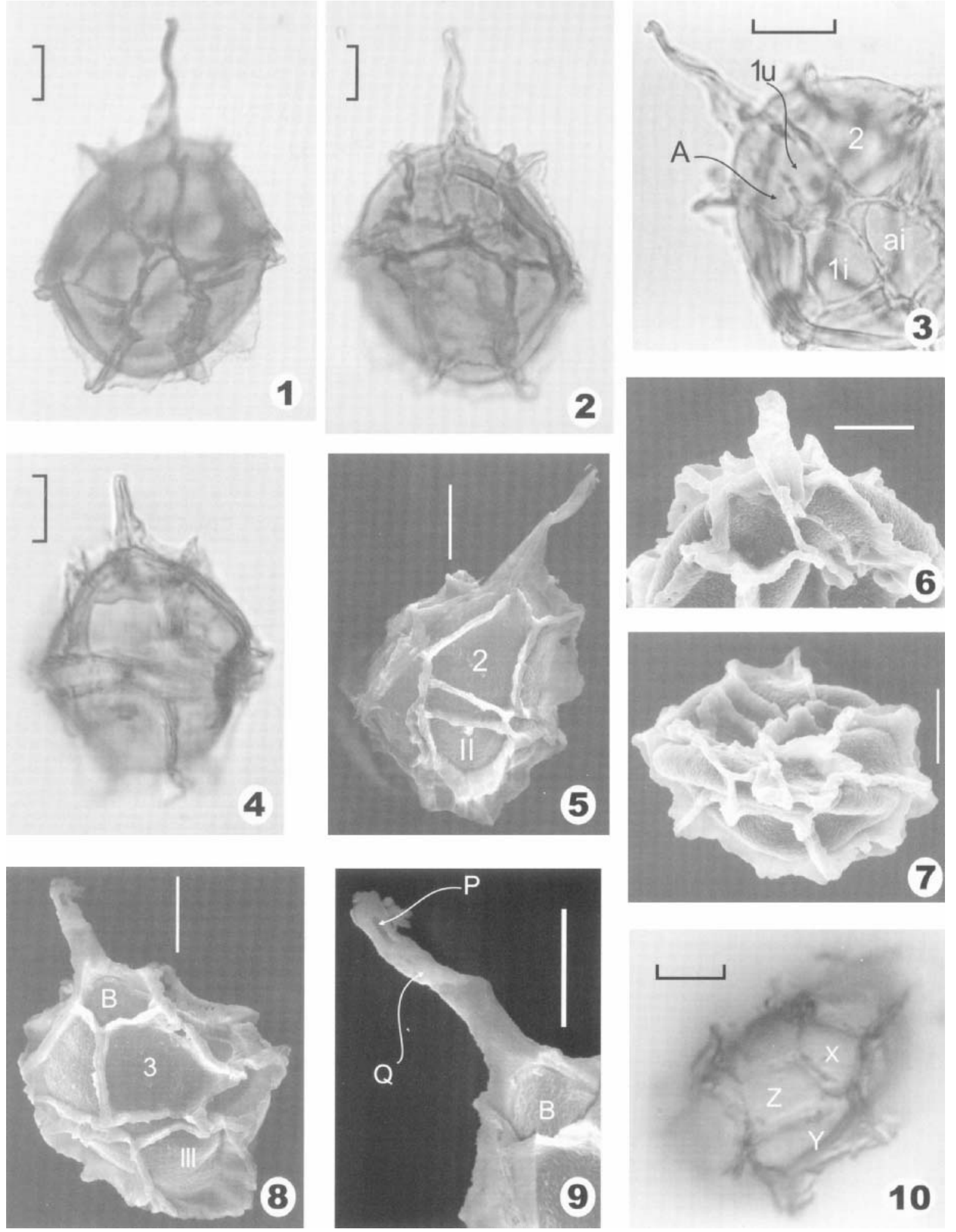

Explanation of Plate 1.

Illustrations of Ynezidinium malloyi. Scale bars equals $10 \mu \mathrm{m}$. Fig. 1. Holotype. Dorsal view of ventral surface with negative reversed. Slide 3 California, Hollister Ranch 72 REM 8620-88u R5048 AJ; CGS Zeiss coordinates 84.2×16.8, American Scientific Microlocator R30. Fig. 2. Holotype. Dorsal view of dorsal surface. Fig. 3. Holotype, close-up of anterior ventral region focused on intersection of paraplates A, $1 \mathrm{u}, 1 \mathrm{i}$ and ai. Fig. 4. Specimen \#1 in glycerine (not preserved), dorsal view focused on reduced archeopyle. Fig. 5. SEM micrograph of specimen 3.007 , left lateral-ventral view. SEM stub \#1sp, CGS collection. Fig. 6. SEM micrograph of specimen 3.001 right-apical-ventral view, $3 \mu \mathrm{m}$ between white scale dots. SEM stub \#1sp, CGS collection (see Fig. 5). Fig. 7. SEM micrograph of specimen 3.001, apical view. SEM stub \#1sp, CGS collection (see Fig. 6). Fig. 8. SEM micrograph of specimen 3.007, left-lateral view. SEM stub \#1sp, CGS collection. Fig. 9. SEM micrograph of specimen 3.007, right-lateral view of apical horn. SEM stub \#1sp, CGS collection. Fig. 10. Specimen \#2 in glycerine (not preserved), posterior sulcal-antapical view. 


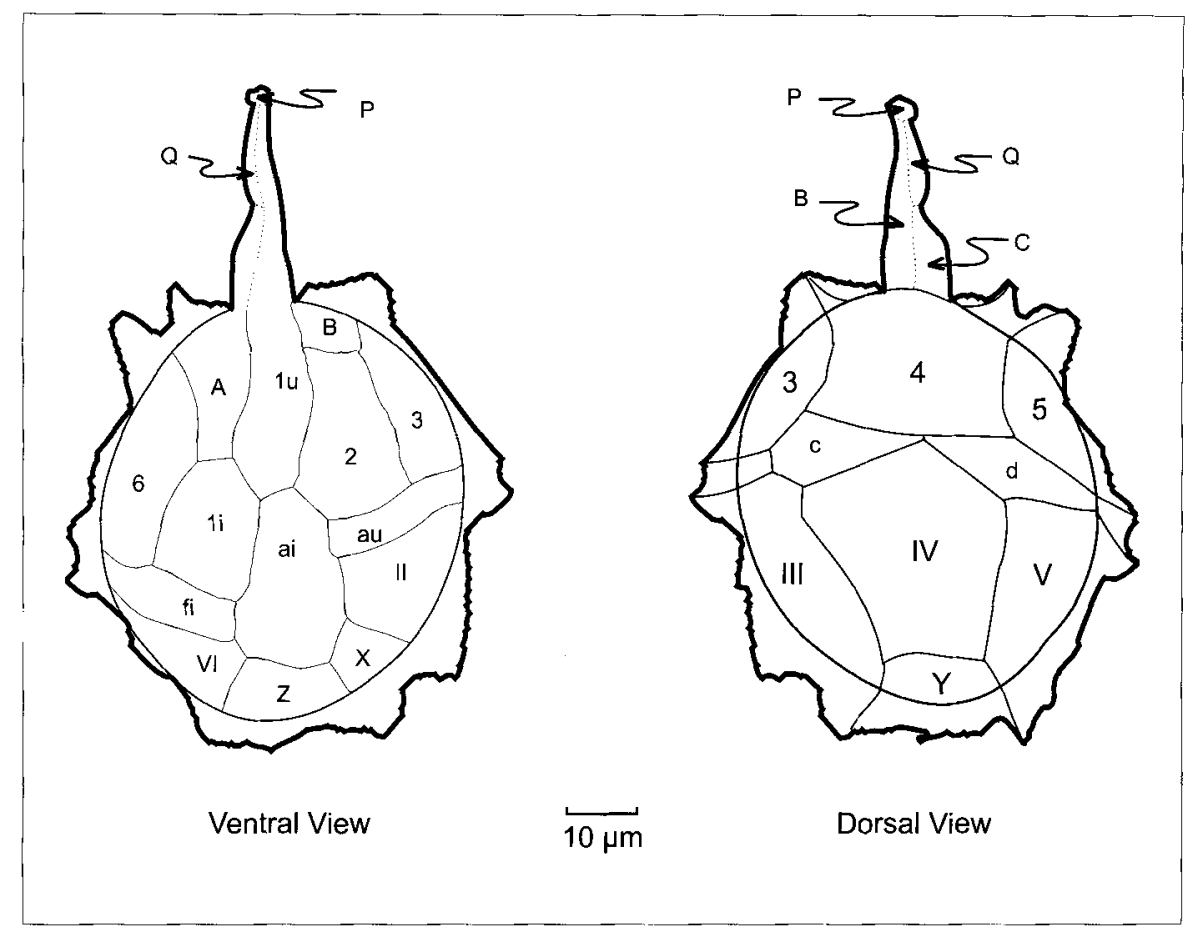

Fig. 4. Diagramatic representations of the holotype of $Y$. malloyi. Dorsal view is external, ventral is internal, reversed. Operculum in place. See Pl. 1, figs 1-3. Thin dashed lines on the apical horn area indicate faint parasutures.

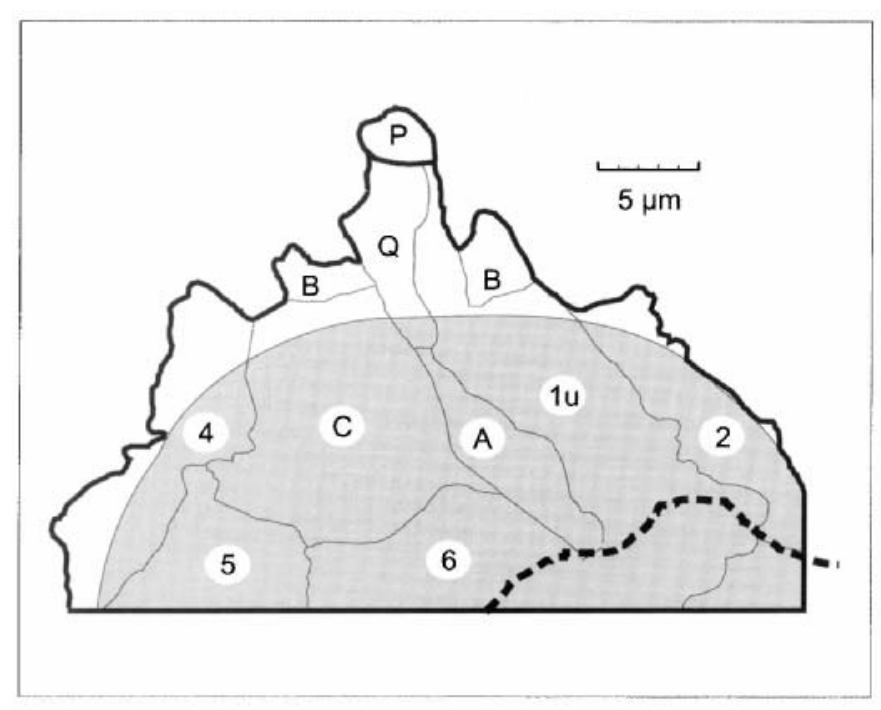

Fig. 5. Right-apical ventral view of a specimen of $Y$. malloyi. Thick dashed line indicates position of fold in the specimen (see Pl, 1, fig. 6).

Holotype. Plate 1, figs 1-3; slide 3 California, Hollister Ranch 72 REM 8620-88u R 5048 AJ; CGS Zeiss coordinates 84.2\TIMES16.8, American Scientific Microlocator R30. Carnegie Museum of Natural History CM 19082.

Type locality and stratum. Arroyo El Bulito, Western Santa Ynez Mountains, Santa Barbara County, California, USA; Anita Formation, Upper Palaeocene, Bulitian Stage, approximately equivalent to NP7 (Figs 1, 2).

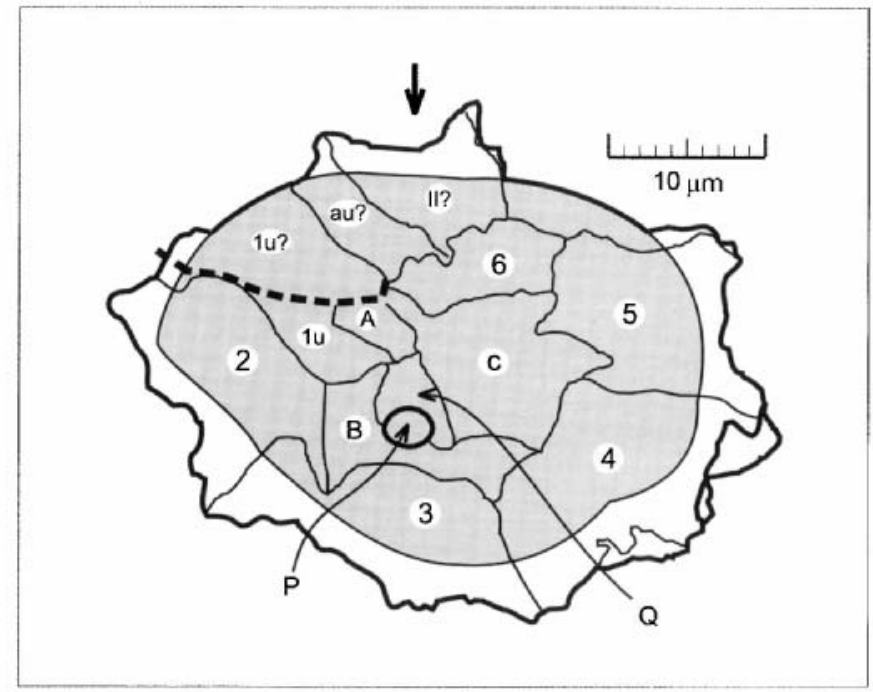

Fig. 6. Apical view of a specimen of $Y$. malloyi with operculum in place. Thick dashed line indicates position of fold in the specimen (see Pl. 1, fig. 7).

Age. Late Palaeocene (Bulitian).

Description. Intermediate size, acavate, subspherical to ellipsoidal cysts with long, prominent apical horn $(10-25 \mu \mathrm{m})$. Paratabulation indicated by parasutural septa or ridges except in the sulcal region. Septa moderately thick, up to $12 \mu \mathrm{m}$ in height, with smooth to slightly serrate edges; may be sparsely perforate. Surface of cyst smooth to very finely granular. Apical paraplates $A$ and $1 \mathrm{u}$ elongate, longitudinally parallel, and of 


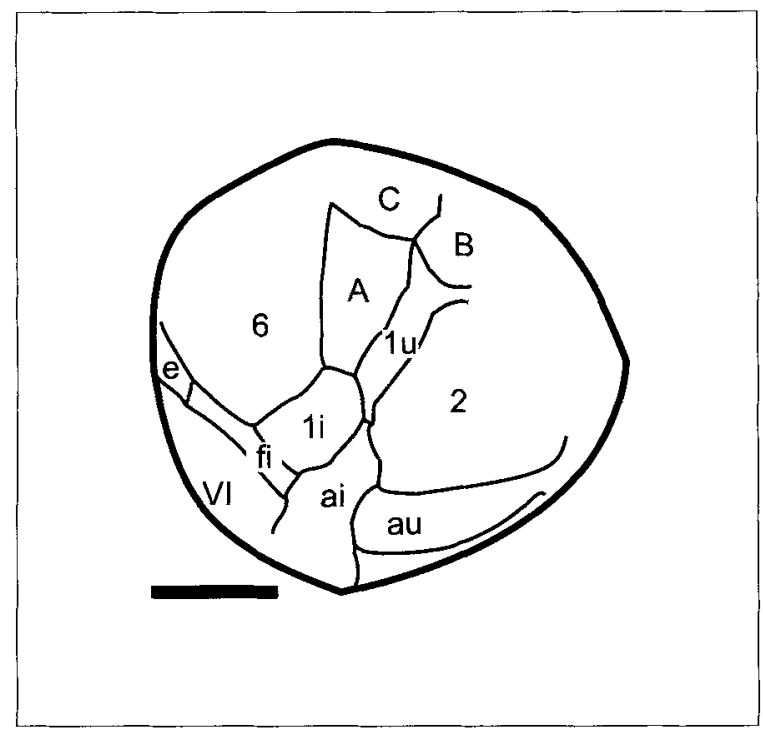

Fig. 7. Line drawing from the holotype of Ynezidinium brevisulcatum comb. nov. Corresponds to pl.56, fig. 4 of Jan du Chêne et al., (1986). Scale bar equals $2 \mu \mathrm{m}$.

approximately equal length; A smaller than $1 \mathrm{u}$. Septum between these paraplates completely developed. Paraplates A, B and C extend up the horn for about half of its length and contact paraplate $Q$. Paraplates 1 $u$ and $B$ contact $P$, which caps the horn and accounts for about one-fifth of its length. Porichnion present at triple junction of $\mathrm{A} / 1 \mathrm{u} / \mathrm{Q}$.

Sixth precingular paraplate (1i) is pentagonal and smaller than the other precingulars. Precingular archeopyle reduced. Loss of operculum occurs within the borders of paraplate 4 , leaving the parasutural septa intact. Operculum simple, free.

Cingulum offset by about $1 \frac{1 / 2}{2}$ cingular widths. Cingular paraplates completely outlined by ridges or septa. Septa in the posterior sulcal region may be incomplete or weakly developed. Paraplates partially outlined include ai, Iu, X and Z.

Dimensions. Holotype central body $40 \mu \mathrm{m}$, total with horn, $62 \mu \mathrm{m} .25$ specimens measured: length including crests and horn $50-70 \mu \mathrm{m}$; diameter of central body $40-50 \mu \mathrm{m}$; horn $6-25 \mu \mathrm{m}$ long. Septa 3-12 $\mu \mathrm{m}$ high.

Occurrence. Reported only from type locality, Arroyo El Bulito, Western Santa Ynez Mountains, Santa Barbara County, California, USA.

Remarks. Ynezidinium malloyi is easily recognized by its prominent horn, ventral paratabulation pattern, smooth wall, and strongly developed septa and ridges.

Ynezidinium brevisulcatum (Michoux 1985) comb. nov. (Fig. 7)

Basionym. Impagidinium brevisulcatum Michoux, 1985, pp. 144 145, pl. 1, figs 9, 10, 11; text-fig. 4 .

Occurrence. Middle Eocene of southwestern France.

Remarks. According to Michoux (1985), Y. brevisulcatum has no apical horn and no indication of the preapical paratabulation. It is otherwise very similar to $Y$. malloyi. Its wall is smooth or

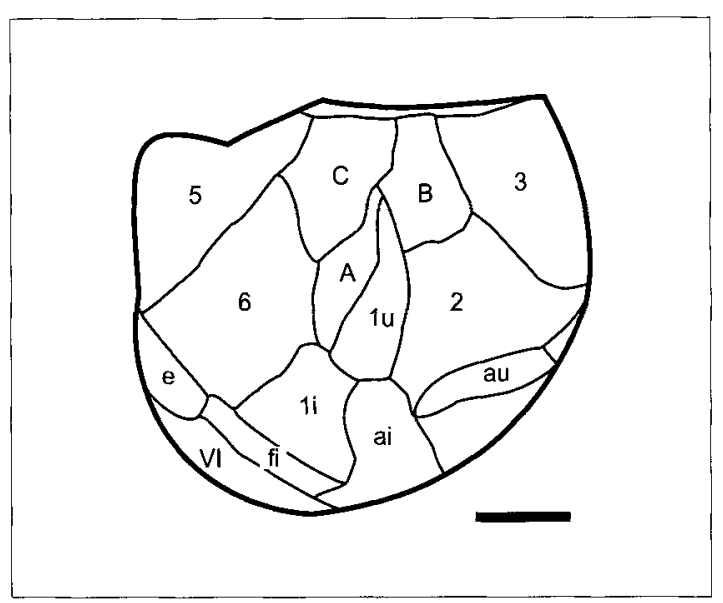

Fig. 8. Line drawing from the paratype of Ynezidinium latolineatum comb. nov. Corresponds to pl. 70, fig. 7 of Jan du Chêne et al. (1986). Scale bar equals $2 \mu \mathrm{m}$.

ornamented with small, irregularly placed tuberculae. The parasutural ridges or septa are low, smooth, occasionally perforate, and even in height. The sixth precingular is reduced in size and either rounded or somewhat triangular.

\section{Ynezidinium latolineatum (Yun 1981) comb. nov.} (Fig. 8)

Basionym. Leptodinium latolineatum Yun, 1981, pp. 10-11, pl. 9 , figs 10,15 ; text-fig. 2 .

Emended description. Intermediate size, spherical to subspherical acavate cysts with prominent pandasutural zones on some parasutures. These zones are slightly depressed and marked by ridges or by thin relatively low, distally serrate membranes. Paratabulation indicated partly by pandasutural zones, partly by ridges or septa and as for the genus. Preapical arrangement is weakly or not expressed. Four apical paraplates A, 1u, B, and C are present; $A$ and $l u$ are elongate and parallel and separated by a single complete ridge or septum. The sixth precingular paraplate is reduced in size and pentagonal in shape, with a definite contact with both $\mathrm{A}$ and $1 \mathrm{u}$. Precingular archeopyle is formed by loss of paraplate 4 and is sub-triangular to quadrangular in shape. Cingulum slightly offset. Sulcus elongate; sulcal paratabulation weakly or not expressed.

Occurrence. Santonian, near Esbeck, Westphalia, Germany.

Remarks. The original description of $Y$. latolineatum is translated from German into English in Fensome et al. (1991). Our emendation is intended mainly to revise the interpretation of the paratabulation pattern and is based on Yun's (1981) description and illustrations of specimens. We have interpreted as paraplate $1 \mathrm{u}$, the area described by Yun $(1981$, p. 11) as follows: 'Between paraplates $\mathrm{I}^{\prime}$ and $5^{\prime}$ is an especially wide border zone which resembles paraplate $1^{\prime \prime}$.' Y. latolineatum can be distinguished from other species of the genus by the absence of an apical horn, its spherical shape and by its wide, doubleridged or double-septate pandasutural bands, particularly evident on the hypocyst. Specimens illustrated by Yun (1981) also appear to have a low, reticulate, intratabular ornamentation. 

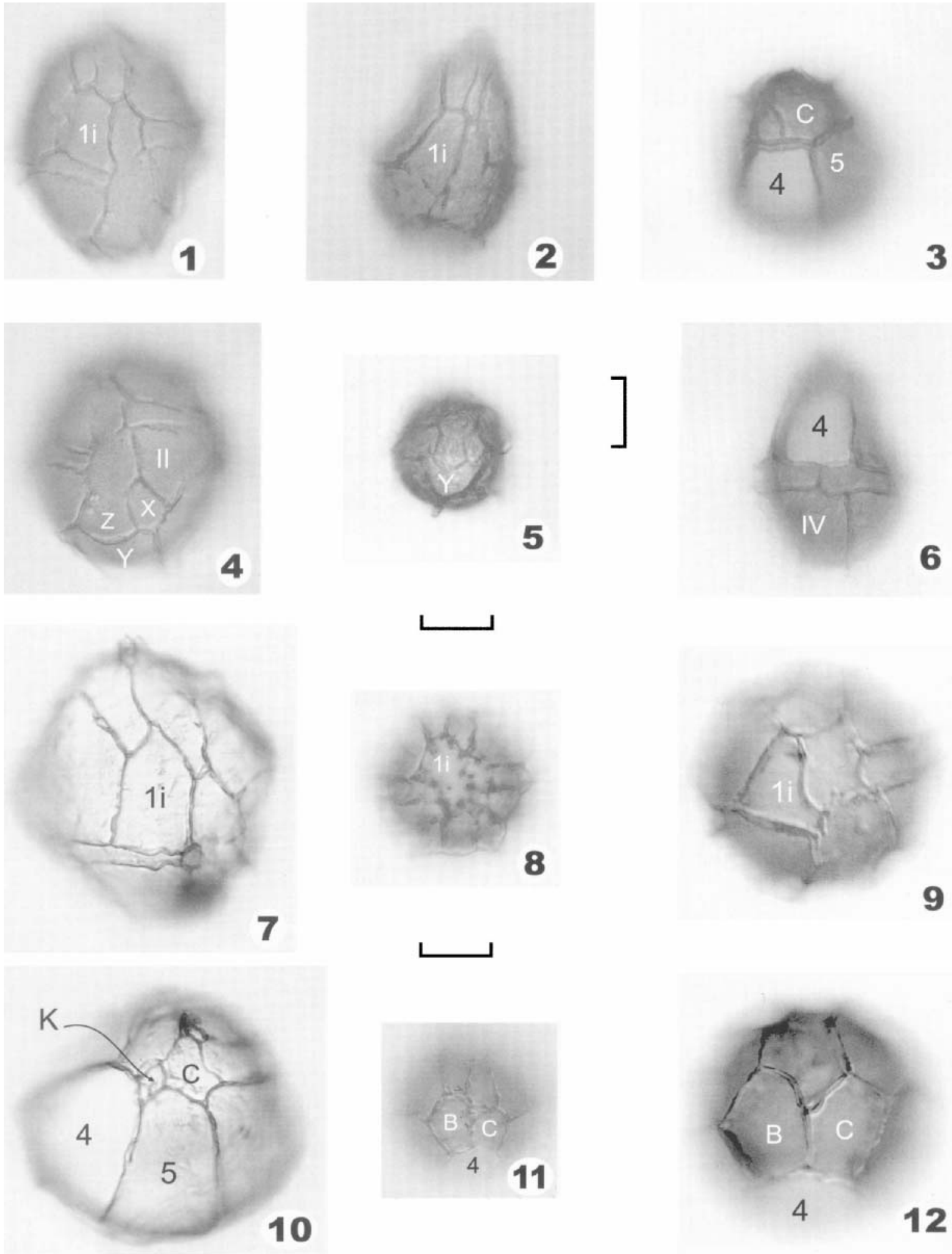

9
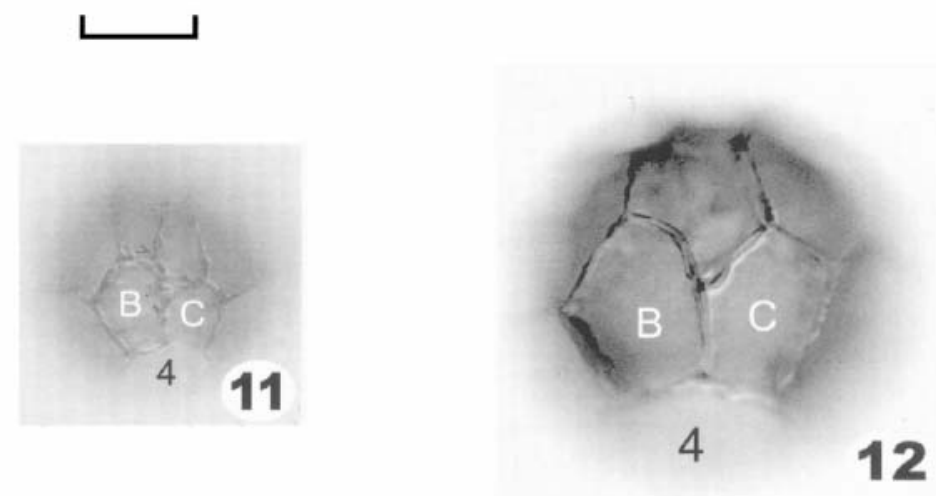

Explanation of Plate 2.

Scale bars equal $20 \mu \mathrm{m}$. Figs 1-6. Ynezidinium pentahedrias: 1, ventral view, note pentagonal shape of paraplate 1i; 2 , ventral view of specimen slightly deformed in the apical area; 3, same specimen as in Fig. 2, dorsal apical view, focused on upper part of archeopyle - note lack of K paraplates on C; 4, same specimen as in Fig. 1, ventral-antapical view, focused on posterior part of sulcus; 5, same specimen as in Fig. 2; antapical view, sulcus to the top; 6, same specimen as in Fig. 2, dorsal view, focused on paraplates 4 and IV. Fig. 7. Leptodinium mirabile; ventral view showing pentagonal paraplate 1i. Fig. 8. Ochetodinium romanum: ventral view, showing pentagonal paraplate li. Fig. 9. Impagidinium californiense: ventral view, showing triangular shape of paraplate 1i. Fig. 10. Leptodinium mirabile: same specimen as in fig. 7. Dorsal-right lateral view, focused on $4 / 5 / \mathrm{C}$ junction, showing K paraplates above the archeopyle. Fig. 11. Ochetodinium romanum, same specimen as in fig. 8. Apical view, showing lack of $\mathrm{K}$ paraplates. Fig. 12. Impagidinium californiense, same specimen as in fig. 9 . Apical view, showing lack of $\mathrm{K}$ paraplates. 


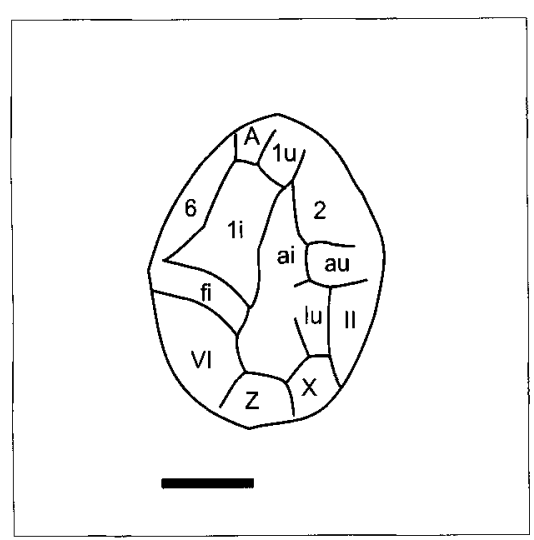

Fig. 9. Line drawing from the isotype of Ynezidinium pentahedrias comb. nov. Corresponds to pl. 59, fig. 12 of Jan du Chêne et al. (1986). Scale bar equals $2 \mu \mathrm{m}$.

\section{Ynezidinium pentahedrias comb. nov.}

(Pl. 2, figs 4, 5, 7, 8; Fig. 9)

Basionym. Impagidinium pentahedrias Damassa 1979: 202-204, pl. 3, figs 22, 24, 25, 26, 28, 29; pl. 4, figs 1-3, 6 .

Occurrence. Palaeocene, Danian of Northern California, near Ukiah.

Remarks. $Y$. pentahedrias lacks an apical horn, and has only weakly developed parasutural indicators of the preapical paratabulation, which do suggest a $Q / B$ arrangement. It is somewhat ovoidal in shape and is more coarsely granular than $Y$, malloyi, the sixth precingular paraplate is more similar in size and shape to other precingulars (rather than reduced in size and rounded).

Ynezidinium waipawaense (Wilson, 1988) comb. nov.

(Fig. 10)

Basionym. Impagidinium waipawaense Wilson, 1988: 24, pl. 13, fig. 1; pl. 14, figs $1-2$.

Occurrence. Early to mid-Eocene, Managaorapan, Heretaungan and Porangan Stages, Waipawa section, New Zealand.

Remarks. $Y$. waipawaense has a relatively short but prominent apical horn, but is distinguished from $Y$. malloyi and other species by its characteristically perforate parasutural septa.

\section{DISCUSSION}

Our creation of another new genus within the family Gonyaulacaceae follows a general trend in the classification of fossil dinoflagellate cysts - towards classification with more emphasis placed on details of paratabulation. Hence, at present there exist some parallel genera which have virtually identical details of paratabulation, but differ in other morphological features. Such is the case with Ynezidinium and Spiniferella. It is also the case with the much larger genera, Spiniferites and Impagidinium. It is tempting to consider merging these genera, even contending that some species, such as Ynezidinium malloyi and Spiniferella cornuta (P]. 2, figs 1,2) might be two cyst stages of the same thecate species, and considering them to be synonymous. However, at the present time no certain evidence seems to be available to demonstrate that a living species of Gonyaulax produces both a cyst with gonal spines and a cyst without them.

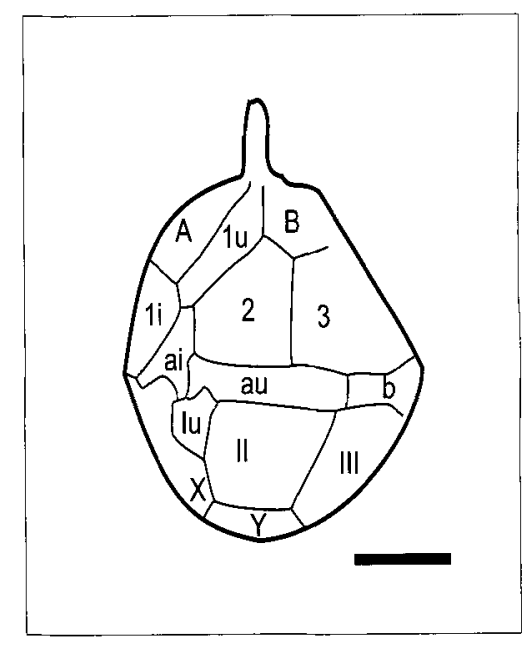

Fig. 10. Line drawing from the holotype of Ynezidinium waipawaense comb. nov. Corresponds to pl. 14, fig. 1a of Wilson (1988). Scale bar equals $2 \mu \mathrm{m}$.

In fact, we are unable to find an example in the literature of a species of Gonyaulax which has been shown to produce a cyst that we would classify as Impagidinium, although we know from Recent sediments that such cysts are being produced by living dinoflagellates. Until we have evidence with which to establish a parallel in the living species of dinoflagellates, it does not seem wise to infer too much about the relationships between species of fossil cysts.

The species assigned to Ynezidinium range in age from Santonian (Late Cretaceous) to middle Eocene. Both Palaeocene species, $Y$. malloyi and $Y$. pentahedrias are found in California and the latter species also in Baja California (Helenes, 1984a).

\section{Acknowledgements}

The authors thank Raymond E. Malloy for his assistance in obtaining the samples, for serving on the academic committee for J. Lucas-Clark at UCSB for the MA degree, and for many hours of assistance with that effort. We also thank Bob Ballog and Dave Vork for assistance at the time of the MA study and for obtaining the slides on deposit with UNOCAL for further study. Bob Oscarson, from the USGS Menlo Park, took the SEM photographs. Jose Mojarro, from the Department of Geology at CICESE, helped with computer processing of some of the photographs.

\section{Manuscript received May 1998 \\ Manuscript accepted May 2000}

\section{REFERENCES}

Below, R. 1981. Dinoflagellaten-Zysten aus dem overen Hauterive bis unteren Cenoman Sud West-Marokkos. Palaeontographica, Abteilung $B$, 176: $1-145$.

Berggren, W. A. 1971. Multiple phylogenetic zonations of the Cenozoic based on planktonic Foraminifera. In Farinacci. A. (Ed.), Proceedings II Planktonic Conference, 41-56. Edizioni Tecnoscienza, Rome.

Clark, J. L. 1981a. Stratigraphic Palynology of the Paleocene and Eocene of the Western Santa Ynez Mountains, Santa Barbara County, California. MA thesis, University of California at Santa Barbara, $197 \mathrm{pp}$. 
Clark, J. L. 1981b. Palynology of the Paleocene and Eocene of the Western Santa Ynez Mountains, Santa Barbara, California (abstract) Palynology 5: 212.

Damassa, S. P. 1979. Eocene dinoflagellates from the Coastal Belt of the franciscan Complex, northern California. Journal of Paleontology, 53(4): 815-840.

Evitt, W. R. 1985. Sporopollenin Dinoflagellate Cysts: Their Morphology and Interpretation. American Association of Stratigraphic Palynologists Foundation, 333pp.

Fensome, R. A., Gocht, H., Stover, L. E. \& Williams, G. L. 1991. The Eisenack Catalogue of Fossil Dinoflagellates. New Series. Volume 1. E Schwizerbart'sche Verlagsbuchhandlung, Stuttgart, $826 \mathrm{pp}$.

Fensome, R. A., Taylor, F. J. R., Norris, G., Sarjeant, W. A. S., Wharton, D. I. \& Williams, G. L. 1993. A classification of living and fossil dinoflagellates. Micropaleontology Special Publication, 7, 351 pp.

Fredericksen, N. 1989. Eocene sporomorph biostratigraphy of southern California; Palaeontographica, Abteilung B, 211: 135-179

Gibson, J. M. 1976. Distribution of planktonic foraminifera and calcareous nannoplankton, Late Cretaceous and Early Paleogene, Santa Ynez Mountains, California. Journal of Foraminiferal Research, 6(2): $87-106$

Helenes, J. 1984a. Dinoflagellates from Cretaceous to Early Tertiary rocks of the Sebastian Vizcaino Basin, Baja California, Mexico. In Frizzell, V. A. Jr. (Ed.), Geology of the Baja California Peninsula, 80106. Pacific Section of the Society of Economic Paleontologists and Mineralogists, 39.

Helenes, J. 1984b. Morphological analysis of Mesozoic-Cenozoic Cribroperidinium (Dinophyceae), and taxonomic implications. Palynology 8: 107-137.

Helenes, J. 1986. Some variations in the paratabulation patterns of Gonyaulacoid dinoflagellates, Palynology 10: 73-110.

Jan du Chene, R., Masure, E., Becheler, I. et al. 1986. Guide pratique pour la determination de kystes de Dinoflagelles fossiles. Le complexe Gonyaulacysta. Bulletin des Centres de Recherches ExplorationProduction Elf-Aquitaine, 12: 1-479.
Kelley, F. R. 1943. Eocene stratigraphy in the western Santa Ynez Mountains, Santa Barbara County, California. American Association of Petroleum Geologists, Bulletin, 27 1-19.

Kleinpell, R. M. \& Weaver, D. W. 1963. Oligocene biostratigraphy of the Santa Barbara embayment, California, University of California Publications in the Geological Sciences 43: 165-250.

Lentin, J. K. \& Williams, G. L. 1993. Fossil Dinoflagellates: Index to Genera and Species, American Association of Stratigraphic Palynologists, Contributions Series 26: 856 pp.

Mallory, V. S. 1959. Lower Tertiary biostratigraphy of the California Coast Ranges, American Association of Petroleum Geologists, Tulsa, OK, $416 \mathrm{pp}$.

Martini, E. 1971. Standard Tertiary and Quaternary calcareous nannoplankton zonation. In Farinacci, A. (Ed.), Proceedings II Planktonic Conference, 2: 739-785. Edizioni Tecnoscienza, Rome.

Michoux, D. 1985. Palynostratigraphie de l'Eocene de Montfort-enChalosse (Landes, France). Revue de Micropaleontologie, 28: 138-153. Morgenroth, P. 1966. Mikrofossilien un Konkretionen des Nordwesteuropäischen Untereozäns. Palaeontographica, Abteilung B, 119: 1-53.

Stover, L. E. \& Evitt, W. R. 1978. Analyses of pre-Pleistocene organicwalled dinoflagellates. Stanford University Publications, Geological Sciences, 15: 1-300pp.

Stover, L. E. \& Hardenbol, J. 1993. Dinoflagellates and Depositional Sequences in the Lower Oligocene (Rupelian) Boom Clay Formation, Belgium. Bulletin de la Société belge de Géologie, 102 (1-2): 5-77.

Sullivan, F. 1964. Lower Tertiary nannoplankton from the California Coast Ranges I, Paleocene. University of California Publications in the Geological Sciences, 44 (3): 163-228.

Taylor, F. J. R. 1980. On Dinoflagellate Evolution. Biosystems 13: 65108.

Wilson, G. J. 1988. Paleocene and Eocene Dinoflagellate Cysts from Waipawa, Hawkes Bay, New Zealand. New Zealand Geological Survey Paleontological Bulletin, 57.

Yun, H.-S. 1981. Dinoflagellates aus der Oberkreide (Santon) von Westfalen. Palaeontographica, Abteilung B, 177(1-4): 1-89. 